\title{
LA (A)CULTURA(CIÓN) DE LA IMAGEN
}

\author{
Manuel GONZÁLEZ DE ÁVILA \\ Universidad de Tours (Francia)
}

Resumen: El análisis del flujo de imágenes contemporáneo parece requerir tanto el apoyo de los modelos de la semiótica general como la participación de una teoría de la cultura que emplace aquél en el seno de la configuración histórica donde las imágenes son producidas, circulan y desarrollan sus funciones cognitivas y sociales.

Résumé: L'analyse du flux contemporain d'images semble requérir aussi bien de l'appui des modèles de la sémiotique générale que de la participation d'une théorie de la culture capable de le resituer à l'intérieur de la configuration historique où les images sont produites et soumises à circulation, et où elles assument leurs fonctions cognitives et sociales.

Palabras clave: Imagen. Iconosfera. Logosfera. Sociosemiótica.

Mots clé: Image. Iconosphère. Logosphère. Sociosémiotique. 
¿Quién puede soportar una imagen más? Y ¿quién podría vivir sin una imagen más? Este dilema no concierne sólo a las masas anónimas de consumidores de las sociedades tardo y postmodernas, sino también a los intelectuales en general y a los miembros de la comunidad científica en particular. En efecto, se quiera o no aceptar que vivimos en una cultura de la imagen, se esté o no dispuesto a emplear categorías fáciles y más propias de la retórica periodística que del discurso de la filosofía o de la ciencia, como la que opone la galaxia Gutenberg (el pasado letrado) al universo Marconi (el presente-futuro cibernético), lo cierto es que hoy todo el mundo está al corriente tanto del proceso de espectacularización y ficcionalización al que se ha sometido a la realidad social por medio de la imagen como de la multitud de teorías que lo analizan, y a veces lo legitiman acríticamente, con indisimulada aquiescencia ante él. Lo que en cambio se echa en falta es un movimiento intelectual que sobrepase la mera comprobación de que el logos va perdiendo la partida frente a las extraordinarias posibilidades de explotación política, económica y social de la iconosfera; un movimiento que, superando la iconodulia beata y la iconofobia rudimentaria, vuelva a preguntarse por las relaciones entre la imagen y la palabra, aún a riesgo de comparar lo que se pretende incomparable, o más bien con el fin de correr ese riesgo y de romper de una vez con un tabú científico actual: el de la presunta irreductibilidad de la imagen a la crítica lingüística, el de su soberana autonomía frente a la lógica natural del lenguaje. Porque si los detentadores del lenguaje, los intelectuales, abandonan la defensa de la razón del logos frente a la pulsión escópica, frente a la necesidad coercitiva de reducirlo todo a imagen, a contemplación sin permanencia ni transcendencia, ¿quién amparará el derecho a la palabra, y con él al combate ideológico, y con él a la lucha por una existencia más justa en el seno de una sociedad reconciliada?

Ahora bien, este programa de resistencia contra la despótica saturación de nuestros ojos, y de recuperación correlativa de la palabra, oral y escrita, debe de apoyarse sobre algo más que críticas apocalípticas o grandilocuentes declaraciones de intención. La razón del lenguaje ha de sostenerse merced al ejercicio demostrativo de sus prerrogativas esenciales: el análisis, la argumentación, el concepto. ¿Por qué no comenzar la tarea de enfrentar lengua e imagen cotejando justamente las posibilidades de una y otra respecto de un concepto teórico, el de función, al que sería urgente ver regresar al campo de la ciencia? Dicho de otro modo, puesto que sabemos con bastante precisión cuáles son las funciones desempeñadas o desempeñables por el lenguaje, ¿no resultaría también interesante indagar cómo se comporta la imagen, y sobre todo la imagen mediática, los artefactos visuales masivos, en relación con 
ellas? Operación que exige aceptar un presupuesto contrario al mencionado tabú: el de que la imagen y la palabra comparten ese mínimo de identidad que hace legítima su comparación funcional. Por muy heterogéneas que sean sus formas de actuar, el icono y la palabra (oral o escrita) son dos variedades del signo, dos vehículos de la significación y de la comunicación interhumanas. Lo cual no impide que las funciones elementales del signo por ambos cumplidas se diferencien y distorsionen en el espacio cultural mediático hasta el punto de que los usos de la imagen artificial vengan a ser como la deformación caricaturesca de lo que idealmente hacen las palabras dentro de una también ideal situación de comunicación. Pues la teoría en las ciencias sociales y humanas no puede no recurrir a un cierto grado de idealización de los contextos por ella aprehendidos, ni de abstracción en sus modelos explicativos de dichos contextos. Valga esta constatación como disculpa anticipada por la injusticia hacia la diversidad de lo real que, en mayor o menor medida, la teoría siempre comete.

\section{REFERENCIA Y SIMULACIÓN}

De entre los asuntos de que se ocupan las ciencias del lenguaje, pocos han dado lugar a tantas, y tan escolásticas discusiones, como el de decidir si los signos de la lengua se refieren a lo «real» o si por el contrario están condenados a funcionar en circuito cerrado dentro del sistema de la cultura, no teniendo entonces como referencia sino su propio despliegue y las modalidades de su significación. Asunto de todavía mayor relevancia para los signos icónicos que para los lingüísticos, ya que en los primeros, y sobre todo en la fotografía, el filme o el vídeo con pretensiones documentales, la referenciaciónrepresentación casi literal del «mundo de la vida» constituye una de sus reivindicaciones inalienables, su genuina razón de ser. Sin embargo, en los términos en los que habitualmente se desarrolla, calcados del universo de discurso de la filosofía del lenguaje, el debate tiende a extremarse - las imágenes-documento o bien son subrogados de lo real o bien son puros artefactos convencionales-, y a ignorar el auténtico estado de hecho de este problema en el seno de la experiencia social, y por consiguiente en el plano de la única «realidad» directamente accesible.

Es ya ocioso precisar que en la génesis de todo cliché fotográfico o fílmico, y de toda imagen videográfica, hay un alto grado de convencionalidad, e incluso de arbitrariedad: la fotografía de una mujer no es el ser humano, como el mapa no es el territorio (Hayakawa, 1972); una y otro son productos de una manufactura intencional. Pero la imagen foto o videográfica, ya sea 
estática o móvil, inventa su propia necesidad como reflejo del horizonte óntico a través de la historia técnica y cultural del hombre: el retrato de una mujer que es nuestra abuela deviene una emanación indicial de ésta mediante el consenso civilizador que nos enseña a considerar las fotografías de familia como huella, trazo o registro, como pasado materializado y testimonio de quienes lo poblaron. Y contra ese género de consenso es inútil elevarse, insistiendo obstinadamente en la arbitrariedad de toda representación visual y en su producción en el interior de un dispositivo tecno-ideológico, porque la creencia en su motivación es ya constitutiva de la estructura y de las prácticas cognitivas de la humanidad. Incluso de aquella parte de la humanidad que, dada al escepticismo por razones profesionales, puede ponerla en duda y relativizar la creencia constitutiva como «efecto de creencia», y el realismo como «efecto de realidad»: del mismo modo que sólo la prioridad antropológica del concepto de verdad hace posibles las discusiones sobre la des-fundamentación de la verdad y las hipótesis del relativismo radical, las imágenes-registro, con independencia de todo trucaje o mistificación referencial imaginables - hoy tan fáciles gracias a la tecnología digital que ya se ha denunciado nuestra entrada en una era "postfotográfica» de la desconfianza (Mitchell, 1992)_, hablan del mundo y hablan el mundo, pues se han integrado entre las condiciones de posibilidad cuasi transcendentales de su aprehensión a lo largo de la historia del género humano.

Así, resuelta —o tal vez eludida — la disputa, que como hemos visto no puede zanjarse en términos exclusivamente semióticos, sino de civilización, lo que queda por saber no es tanto si las imágenes-documento representan lo real como si lo real no se ha convertido, a fuerza de inventarios visuales, en pura representación, es decir, si no se ha pasado del efecto de creencia en el realismo del icono (en el poder constatativo de éste) a la creencia en el efecto de la iconización de la realidad (en la facultad ontogenética de dicha iconización). La respuesta que a tal interrogante han dado desde hace al menos dos décadas ciertos analistas de la cultura resulta no por conocida menos memorable (Baudrillard, 1993; Virilio, 1997): según aquéllos, lo real tendería a desaparecer, a desmaterializarse y volverse virtual por el exceso de sus sustitutos visuales; lo real habría quedado sumergido por un flujo incesante de iconos que no sólo desaprenden al ojo a contemplar las cosas, porque ya se han visto todas previamente esquematizadas en los medios de comunicación, sino que las reemplazan por una procesión inacabable de simulacros hiperreales, más eficientes y eficaces que los «experienciables» del truncado mundo de la vida. Así, en el dominio subjetivo el libro de viajes o el documental sustituyen con ventajosas la prueba somática del desarraigo, 
el videojuego la del esfuerzo muscular, y la vivencia vicaria de la pornografía se impone sobre la práctica vital del sexo; en los tres casos al sujeto se le facilita un control sistemático de su intensidad pasional con una mínima inversión en tiempo y riesgo «reales». Así también, en el dominio tecnológico, el diseño por ordenador permite una matematización de lo visible tal que pueden formarse innumerables representaciones lúdicas de cualesquiera objetos complejos (un edificio, un avión, un automóvil), desde todos los ángulos y manipularlas a voluntad, con similar economía en variables de costo «real», sin que ello tenga que desembocar en ningún paso al acto concreto de fabricación.

La realidad (lo real instituido) parece en estos tiempos lo fotografiado, filmado o modelado en imágenes de síntesis una y mil veces: cuando una carrera ciclista atraviesa una ciudad, la mayor parte de los habitantes prefiere seguirla por televisión a bajar a la calle, siendo la puesta en escena televisual mucho más rica que el espectáculo en directo; las fotografías de los encuentros interpersonales se han transformado en superobjetos que funcionan como condensadores (como «atractores morfogenéticos», en la muy especializada pero precisa terminología de la teoría matemática de las catástrofes) de una experiencia de intercambio humano por lo demás cada vez más incierta. Ante la objeción siempre pronta de que el sustituto icónico no destruye el hecho ni posee un poder contrafáctico, desrealizador ${ }^{1}$, cabe replicar que no es del todo seguro que la ubicua avalancha de iconos artificiales no contribuya decisivamente a encerrar al sujeto en esa dimensión llamada por J.-P. Sartre lo «imaginario» (Sartre, 1940) — término de tan buena fortuna posterior en las ciencias humanas, donde cuenta con numerosos y a veces ingenuos apologistas- - Sartre no distinguía, en su reflexión, la imagen artificial de la mental, y por tanto tampoco el trabajo material de fabricación de imágenes sobre soporte físico del proceso perceptivo-cognitivo de interpretación de aquéllas, o de elaboración de otras sin que medie ningún acto perceptivo. Y tampoco diferenciaba claramente entre «lo imaginario» y «la imaginación»; para él, la dimensión imaginaria o imaginante de la conciencia se caracterizaba en cualquier caso por estar en permanente tensión hacia sus propias representaciones, distanciándose así de lo real y liberándose de ello. Aunque una teoría científica strictu sensu podría reprocharle la imprecisión de sus conceptos, dicha confusión se revela preciosa para quien se niegue a practicar, por respeto a los límites entre disciplinas académicas, escisiones tajantes en la experiencia, y por eso mismo se resista a separar los

\footnotetext{
${ }^{1}$ S. Sontag (2003) recurre a ella por causas éticamente impecables.
} 
signos sociales por un lado, la cognición por otro, y la conducta por un tercero. Según éste, la imaginación, lejos de ser una facultad vacía o puramente constituyente, es un depósito de representaciones sociales constituidas que la instituyen y la determinan; y ella misma instituye y determina modos de conducta que encuentran su expresión en el mundo de la vida. La imaginación de los sujetos sociales, alimentada sin pausa por las imágenes que las industrias culturales fabrican para ella y que conforman su contenido o imaginario, sólo anonada la realidad para después realizarse a sí misma en su lugar. No hay entonces pérdida de realidad, sino sustitución de una realidad de grado $-\mathrm{n}$ (lo real establecido como realidad social) por otra de grado $-\mathrm{n}+1$ (la realidad social simulada), que se revela a la conciencia extasiada con un poder casi epifánico ${ }^{2}$ : la plétora de imágenes, el simulacro generalizado, se viven con un sentimiento visionario, y el ojo contempla en cada momento de su existir a la suma realidad hecha imagen, al único Dios que se le manifiesta, por fin, idéntico a su icono. Sartre podía percibir, en 1940, en la actividad de la imaginación y la constitución de imaginarios, tan íntimamente amalgamadas como hemos visto, una de las manifestaciones de la libertad fundamental y fundadora del para-sí, del entendimiento humano. El que ahora, tras casi setenta de desarrollo de la semiosfera cultural y de los aparatos tecnocientíficos de producción icónica, interpretar la relación entre los imaginarios y la imaginación según una antropología de la libertad de la conciencia parezca propiamente un dislate intelectual, y que haya en cambio que resaltar el radical desarraigo de la conciencia respecto de lo real y su inmersión irreversible en la marea totalitaria de los simulacros realizados, proporciona a buen seguro ciertos indicios sobre el sentido de nuestra evolución histórica, indisociablemente económica, tecnológica y política.

\section{EMOCIÓN Y TIMOPATÍA}

Del mismo modo que nadie pone en duda el vínculo estrecho existente entre lenguaje y afectividad, tampoco los investigadores separan imagen y humor, imagen y emoción. De hecho, para la semiótica ya en la misma génesis de la imagen natural en el sensorio se halla una polarización emocional del cuerpo que percibe, una tensión somática hacia el objeto percibido que más tarde será modulada por el trabajo de su estructuración cognitiva (Eco, 1999). Si ello es así para la imagen natural, con mayor motivo se impone en-

2 S. M. Eisenstein fue el primero en emplear el término «extasis» para describir los efectos de la imagen artificial sobre su receptor (Einsenstein, 2001). 
tender la imagen artificial o el icono forjado por medios técnicos como una formidable herramienta de explotación y procesamiento, en sentido amplio, del dinamismo emocional de los sujetos consumidores de imágenes. De lo cual da cumplido testimonio no ya sólo el cariz vocacional del trabajo de los profesionales de la cultura visual, sino la consagración al icono por parte de los innumerables aficionados que colman su ocio y gestionan su afectividad fabricando millones de acaso rudimentarios pero rentables —en términos de economía anímica一, simulacros referenciales. El equipo tecnológico básico puesto a su servicio incluye, en funcionamiento de red, la cámara digital (de fotografía y de vídeo), el monitor televisual, el procesador informático con software interactivo conectado a Internet, la impresora color y el escáner, sin contar los viejos medios industriales requeridos por los venerables métodos analógicos aún vigentes. Y en el horizonte de la renovación tecnoeconómica se anuncian ya máquinas de producción de hologramas y más perfeccionados sistemas sinestésicos, multisensoriales, de generación de realidad virtual.

Pero tal furor iconogenésico resultaría incomprensible de no encontrarse, en el otro extremo de esa comunicación especialmente próxima, cálida y carismática que se establece gracias al mensaje-imagen, un receptor aún más ávido de participar en ella que el propio productor de iconos. Pues la comunicación icónica es en nuestros días tan globalmente compartida que ha engendrado una suerte de imprevisible isegoría social — una igualdad en el derecho a la expresión visual-: los productores son también receptores de imágenes, y los receptores, productores, y desde cualquiera de las dos posiciones complementarias el deseo del sujeto se orienta ante todo a insertarse en la corriente emocional unanimista de la sociedad.

En efecto, si no hace mucho podía argumentarse que nuestro universo social funcionaba gracias a la «psicología» (Althusser, 1977), la cual pretendía oficiar a la vez de esencia y de apariencia del entramado de los hábitos y de las conductas de los individuos - además de haberse constituido en paradigma de interpretación «científica» de dichos hábitos y conductas, con lo cual la circularidad entre hecho social y conocimiento del hecho era casi completa, y el déficit epistemológico casi insuperable—, en la actualidad la psicología ha cedido sus privilegios a favor de un actante social aún menos determinable: las intensidades fluidas de lo que los griegos llamaban el thymos, el humor de base, la emoción primaria, a las que la imagen sirve de vehículo idóneo; intensidades ni racionales ni irracionales, ni conscientes ni inconscientes, simplemente proliferantes y permeantes, dotadas del ritmo contagioso de las pandemias arrolladoras. Y al igual que la psicología de ayer, el afecto en sus aspectos menos articulados se ha convertido hoy, gracias a su 
triple elevación a categoría de objeto científico privilegiado (así, sobreabundan las «nuevas» teorías de la emoción), de tema de moda para la doxa (apasionarse por algo y contarlo equivale a autoexpedirse un certificado de normalidad psicosocial), y de agente indubitable del acontecer colectivo (aquí sobran, de tan numerosos, los ejemplos), en parte de la definición dominante de la realidad, y por tanto en sustrato ontológico de ésta. Un sustrato blando, sobre cuya labilidad mal cabría asentar nada que se parezca a las normas explícitas de la Razón o, más modestamente, de una razón común. Porque la emocionalidad elemental y su catalizador contemporáneo, la imagen artificialmente producida, se presentan ambas como lo inmediato por excelencia, como aquello que puede prescindir de todo análisis y justificación; el icono-emoción se injerta en el sujeto y hace de éste una materia porosa, atravesada por una miríada de impulsos afectivos, despojada de una conciencia capaz de fijar y objetivar la experiencia, de elevarla a concepto, como decía con su inestimable grandilocuencia la teoría filosófica tradicional.

La síntesis de imagen y emoción que consumen los sujetos sociales vuelve así irrisoria, en su insalvable distancia histórica, la representación clásica de la imaginación — nutrida de imágenes - como el instrumento mediador entre las facultades del ser espiritual — la mente - y las del ser biológico el cuerpo- (R. Descartes). Lejos de instalar el pensamiento en el cuerpo y el cuerpo en el pensamiento, la imaginación sobrecargada de iconos artificiales se contagia de la saturación eufórica o disfórica de éstos, de su aleatoriedad creciente, de su velocidad frenética, bloqueando todo esfuerzo de regulación cognitiva. La función timopática de la imagen, la hipertrofia de sus componentes emotivos en detrimento de los racionales, fomentada tanto por las prácticas individuales como por los megamedios de masas, desmoviliza más bien al pensamiento, y le priva de todo apoyo corporal ${ }^{3}$.

\section{ORDEN Y AUTORREALIZACIÓN}

Ahora bien, a esta desmovilización general del pensamiento por la imagen y la emoción le corresponde, como su inevitable correlato, un estado de ininterrumpidas alerta e implicación somáticas por parte de los sujetos so-

\footnotetext{
3 No faltan teorías que sostienen lo contrario e insisten en el saber y las competencias que el procesamiento de las imágenes exige de sus consumidores y contribuye a crear en ellos (Bordwell, 1995). Tales teorías adolecen, sin embargo, de un punto de vista excesivamente escolástico y reflejan más lo que el analista hiperintelectual puede extraer de las imágenes que lo que éstas invitan a hacer a sus contempladores espontáneos.
} 
ciales, una movilización permanente de sus cuerpos. Pero no de cualquier cuerpo: no del cuerpo real, pensante, sintiente y sufriente, el cuerpo atravesado por la historia individual y por la historia colectiva -indisociables-, sino de la prótesis simbólica que ha venido a sustituir al cuerpo físico (Bettetini, 1984), de esa prolongación perceptiva que sale de cada cual al encuentro de la embajada perpetua de los iconos artificiales, y que vive por nosotros la experiencia vicaria a la que nos invitan o nos arrojan las industrias de la cultura. La pulsión escópica inducida en el sujeto a través de la larga socialización de la mirada, del inacabable ritual de seducción del ojo por la imagen fabricada, crea una tensión somática en la que el cuerpo real se desvanece, apareciendo en su lugar un proyecto sensorial permanente, el de un segundo cuerpo fantasmático directamente conectado con la fuente emisora de las imágenes, usufructuario de una infinitud de mundos posibles, caleidoscópicos y mutantes, en los que se participa pero de los que sin embargo nunca se llega a formar plenamente parte... porque en un cosmos de simulacros visuales no cabe hallar morada y habitar. La mirada tardo y postmoderna está condenada a una hiperactividad crónica, a un nomadismo errático y frustrado, nunca llegado a ningún destino, pues no hay para aquélla otra meta que no sea continuar su propio movimiento. Y del mismo modo que esa mirada no logra penetrar en lo mirado y apropiárselo, ya que lo mirado es una ficción y quien lo mira un actor anónimo despojado de su cuerpo, así la movilización perceptiva de tal muchedumbre de prótesis simbólicas tampoco consigue componer genuinos grupos, verdaderas solidaridades organizadas en torno a previsiones compartidas. Los cuerpos fantasmáticos que viven lo real como un espectáculo y que se nutren de emociones preconstruidas son un ejército de mónadas aisladas, homogéneas en su forma, pero incapaces de intercambiar sus vivencias semialucinatorias para constituirse en actor social colectivo, provisto de una intencionalidad común y dotado de un objeto de valor hacia el que hacer converger la acción.

No es casualidad, en efecto, que el más exacerbado individualismo coexista en paz con un gregarismo arrollador en el terreno de las prácticas visuales estándares, que tales prácticas fundan a los individuos en masas y los separen a la par radicalmente a los unos de los otros. La asistencia por televisión a un evento deportivo que se verá en todo el planeta, la búsqueda masiva en Internet de cierto género de imágenes prohibidas por la ley, o incluso esa variedad en boga de turismo ocular en la que los viajeros permanecen perfectamente encajados e inmóviles en los asientos de su vehículo mientras desfilan tras la ventanilla los decorados — pura imagen, imagen impuracon los que alimentarán su apasionante sensación de haber estado allí y de 
haberlo visto, son otras tantas revelaciones de que la experiencia visual contemporánea y los contenidos afectivos en ella explotados sostienen una singular forma de comunicación que no crea comunidad, como corresponde a un hecho sensorial que no se vive con el cuerpo real, sino con una prótesis descarnada, y a un suceso perceptivo que no desemboca en la cognición. De ahí justamente el que surja la perplejidad al trasvasar al estudio de la imagen artificial aquella función impresiva o conativa que la teoría de la información y las ciencias del lenguaje asignaban a los actos lingüísticos como una de las posibilidades operativas de la comunicación: la de transmitir órdenes. Si ni la inteligencia ni el cuerpo de los receptores de las imágenes artificiales participan activamente en su procesamiento, si es preciso concebir al destinatario de la producción icónica como un haz de emociones en constante reestructuración, una proyección autoplástica e inmaterial, ¿resulta todavía adecuado hablar de conductas provocadas u orientadas por los signos, por los contenidos de la comunicación y por la voluntad de la fuente emisora? La respuesta es, con todo y con matizaciones, sin duda afirmativa, e incluso más afirmativa que nunca. Pues le corresponde a la dominante cultura de la imagen el mérito de haber transformado un instrumento semiótico relativamente poco fiable, el icono artificial, no muy codificado y por tanto en exceso ambiguo e inestable, en pieza clave de un nuevo tipo de control cibernético: un control comunicativo cuyo mayor éxito consiste en imponer sobre los destinatarios pautas de conducta (lo que el filósofo Ch. S. Peirce llamaba «interpretantes finales») reproductoras de las modalidades mismas de estructuración y desestructuración caóticas de los signos icónicos que las producen.

Al igual que se torna cada vez más difícil descubrir en los fragmentos de imágenes de los medios un proyecto de sentido apoyado sobre sus inseguras cohesión y coherencia internas, la neocomunicación icónica, considerada como flujo estadístico y aleatorio, no prescribe nada concreto al individuo, según el modelo de un conductismo estrecho: muy al contrario, se desentiende del individuo, contentándose con realizarse a sí misma, autoperformativamente, sin tregua ni vacilación. Así cubre el horizonte, absorbe la totalidad de los objetos y valores en él presentes, y vuelve ociosa cualquier orden explícita. Esta sofisticada y paradójica maquinaria del control por la imagen, de gran rentabilidad política y económica, no necesita hoy guiar las reacciones de los sujetos sociales en una u otra dirección, ya que todas ellas le son mayormente indiferentes, como indiferentes le resultan, en última instancia, todos los contenidos, por inocuos: lo único que de verdad le hace falta es que los receptores no se desmovilicen jamás, que el frenético dinamismo con el que abren sus cuerpos fantasmáticos a la corriente de los simulacros visuales car- 
gados de afecto no decaiga ni un instante. De esa suerte se realiza en la realidad, como suelen hacerlo las utopías negativas, aquella socialización integral en la disponibilidad sin condiciones de los individuos que los teóricos del fascismo habían previsto en la primera mitad del siglo XX (Junger, 1990), si bien la anticiparon bajo un modo físico, mecanizado e industrial, definitivamente obsoleto en sociedades que han escogido entenderse a sí mismas como virtuales. En la iconosfera de tales sociedades no podría haber órdenes propiamente hablando, no tanto porque la imagen sea un mal inductor del poder (que no lo es) como porque las prescripciones, según el viejo modelo democrático y liberal de la teoría de la comunicación, para ser operativas tienen que interpretarse como legítimas por sujetos racionales y cooperativos, que participen en un sentido colectivo y sean relativamente dueños de su conducta; y son precisamente esos sujetos lo que impiden consolidar las difusas experiencias de sentido contemporáneas, en constante construcción y deconstrucción, y cuya única normatividad se cifra en circular aceleradamente, generando efectos de realidad que se agotan en su propia producción y consumo.

\section{CONTACTO Y SATURACIÓN}

A afirmar ese tipo de desaparecidos sujetos podía en cambio contribuir la antigua comunicación —en especial la comunicación no mediada, a la que no sería demasiado irónico llamar la paleocomunicación — a través del cuidado puesto en la dimensión relacional de su proceso. Pues comunicar no es sólo, ni siquiera fundamentalmente, codificar, transmitir y descodificar: emisor y destinatario han de ocuparse asimismo de mantener en buen estado tanto el sistema de códigos que comparten como el canal a través del cual éstos viajan, asegurándose de que nada lo obstruye y reparándolo en caso de que presente otras anomalías o desperfectos. Así, por ejemplo, la comunicación por la palabra rebosa de intervenciones llamadas «fáticas» que aseguran su estabilidad: no sólo la protegen los consabidos rituales de la interacción dialógica estudiados por la etnometodología y el análisis del discurso (los saludos y despedidas con que se abre y cierra el contacto entre sujetos, las fórmulas de cortesía que lo facilitan y orientan, los indicadores de la disposición al cambio de turno, etc.), sino que también se vigila su desarrollo gracias a incesantes regulaciones que corrigen las disonancias potenciales entre coenunciadores o reestablecen, cuando se ven amenazados, los niveles de consenso requeridos para la prosecución de la relación comunicativa. Lo decisivo en dichas operaciones, ejecutadas, con algunas diferencias, tanto en el caso de la comunicación oral como de la escrita, es que son fruto de una negociación entre sujetos, de una tran- 
sacción social cuyas reglas no han sido establecidas por los propios sujetos, pero sobre las que éstos pueden ejercer cierto control positivo o negativo (el negativo a riesgo de hacer saltar por los aires su intercambio).

Pero en la comunicación tecnocientífica las cosas suceden ahora de muy distinto modo, y una vez más la comparación entre la teoría del lenguaje (idealmente normativa por necesidad) y el estado de facto de la semiosfera permite iluminar los cambios en nuestros regímenes de sentido, y en consecuencia también los derroteros de nuestra historia social. Dadas las mentadas distorsiones que en la comunicación de masas sufre el democrático esquema «emisor-mensaje-código-canal-contexto-destinatario», y considerada sobre todo la imposibilidad para el emisor de recibir en tiempo real un feed-back o respuesta reguladora del destinatario, aquél se ve obligado a reabsorber de antemano en el mensaje el componente fático que en principio debiera impregnar la totalidad del acto comunicativo. Y ello con el fin de que sea el propio mensaje el que ritualice la interacción, prevea las objeciones y resistencias posibles del destinatario, y llegue a compensarlas por anticipado. Tarea que, resultando sólo parcialmente ejecutable en el texto escrito, se vuelve aún más difícil en la comunicación visual, ya que los iconos no parecen poseer plenamente los medios adecuados para garantizar el contacto como una de las condiciones elementales de felicidad del intercambio comunicativo.

Las imágenes artificiales son brutalmente concretas e imperativamente autoritarias: su simple estar-ahí, su mero comparecer, equivalen ya a un mandato de percepción sin atenuantes. ¿Cómo se las arreglan entonces las instancias emisoras para resolver esta carencia y adelantarse a cualquier rechazo del injerto visual por parte del organismo receptor? Primera hipótesis: promoviendo una iconosfera básicamente demagógica, una enciclopedia visual de la identidad icónica, de suerte que el muy alto índice de prototipicidad y normalización de los percipienda que la componen fuerce la aquiescencia del destinatario. Opción válida y asumida por buen número de los productores de iconos, pero que presenta la conocida desventaja de disminuir la informatividad de las imágenes, y por tanto su poder de seducción, en la misma medida en que aumenta exponencialmente su redundancia, es decir su previsibilidad. A este problema se enfrentan, por ejemplo, los especialistas en propaganda política al poner en marcha el componente icónico de las campañas electorales, que ha de respetar con todo escrúpulo los parámetros de la normalidad mesocrática sin por ello resultar del todo plano. Segunda hipótesis: combinando sabiamente identidad y alteridad visuales, iconos estereotipados que la memoria reconozca de inmediato como suyos y en los que el espectador pueda proyectarse - confiando a dicha proyección la generación del mínimo necesario de energía 
fática-, y otros innovadores, insólitos y no normalizados. Eso es lo que sucede en la promoción publicitaria de productos estrechamente vinculados al cuerpo del individuo y a su burbuja personal —el tabaco, los cosméticos, y últimamente los medicamentos y la cirugía plástica-, con los que los consumidores suelen entablar delicados vínculos de identificación psicosocial, tan difíciles de anudar como de romper una vez anudados.

Sin embargo, ninguna de estas dos hipótesis, impecablemente académicas, logra aprehender el funcionamiento efectivo de nuestra iconosfera en su globalidad, el inverosímil sobreesfuerzo de semioproducción que en ella se lleva a cabo en todo momento, y sus derivaciones. La primera hipótesis, porque responde a una lógica de la repetición de la experiencia visual que ya no es estrictamente indispensable para la conservación de la sociedad: ésta muda sin descanso sus apariencias - lo único que capta el ojo y la imagen-, sin que ello perjudique en nada a la reproducción de sus constantes estructurales (la subsistencia del «efecto de moda» en las distintas prácticas sociales da prueba de ello). La segunda, porque la aleación tornasolada de las imágenes artificiales, que fluye densamente desde los centros de emisión y se expande por todo el globo, funde en efecto redundancia y ruido, orden y aleatoriedad, prototipicidad y teratología, pero no según criterios de compensación o de equilibrio, sino en función de una casualidad combinatoria que no es una lógica, puesto que las desafía a todas, incluso a la del desarreglo premeditado. La iconosfera actual prescinde de hecho de la función fática como de un residuo arcaico del pasado y de su racionalidad comunicativa; en su lugar implanta otra saturativa, una función consistente en colmar cada fragmento del espacio con una imagen, dando muestras de la ya aludida indiferencia hacia su contenido $\mathrm{y}$ haciendo caso omiso de la actitud al respecto del receptor.

Un campo visual saturado, en permanentes formación y disolución y cuyas regulaciones son relajadamente autocontradictorias, ofrece una experiencia icónica que puede ahorrarse todo trabajo de legitimación: nadie pensaría en pedirle cuentas a un suplemento dominical, que contiene en su interior reportajes sobre guerras y calamidades y publicidad de productos de consumo suntuario, ilustraciones médicas y paramédicas y anuncios de substancias tóxicas, iconos de paraísos artificiales y fotografías de entornos arrasados por la contaminación, sobre la oportunidad de los estímulos visuales por él propuestos, ni sobre la aceptabilidad intersubjetiva de sus comunicados icónicos. Hay, sin embargo, otro motivo por el que ya no importa que la comunicación visual se lleve a cabo respetando ciertos protocolos entre emisor y destinatario, y es que tampoco existen distancias entre ambos en un sistema social en el que los sujetos están voluntariamente involucrados en una doble actividad consabida de producción de 
imágenes de sí mismos y de consumo de imágenes del otro, de consumo de imágenes de sí y de producción de imágenes del otro. A causa de la repleción visual de ambas dimensiones, la social (la iconosfera mediática) y la individual (las prácticas icónicas privadas), no es sólo el contenido temático de la imagen, sino también el axiológico, lo que va sumiéndose en la indiferencia: da igual que el significado de la imagen sea ético o contraético respecto de los sistemas de valores más o menos universalizables que conocemos, y que el receptor desee o no acogerlo por ello mismo en su vivencia, pues se trata sólo de un icono más de entre la suma infinita, en suyo seno se neutraliza, de los virtualmente convocables y consumibles. La evaluación axiológica de la imagen no es ni siquiera concebible cuando el fondo del ojo actúa como encrucijada de un tránsito ininterrumpido de apariciones alternantes, como pantalla inextinguible donde viene a reflejarse un mundo definitivamente desestructurado y metamórfico, y por tanto esencialmente mágico. Si la función crítica de la conciencia exige cierto grado de alienación, de ruptura con la realidad, la competencia crítica de la vista precisa alejarse de lo percibido para poder discriminar y juzgar. Cuando ni la conciencia se arranca de lo real ni la mirada rechaza nada de lo visible, la crítica es imposible y la ataraxia última está cercana. En esas condiciones, ¿a quién pueden importarle los rituales de protección del contacto en la comunicación o, como se dijo antes, de la construcción de sujetos autónomos, que se definen justamente, entre otras cosas, por su dominio autoconsciente de la ritualización social? No desde luego a los estrategas publicitarios de la firma Benetton, a los psicosociólogos particulares de compañías de seguros como Axa o a los semiólogos a sueldo de Nike. En un hiperespacio en el que cabe volver invisible lo visible (la fealdad primaria de la miseria social) y visible lo invisible (las ficciones de la compensación alucinatoria), el campo visual fabricado puede tanto obligar a mirar lo insostenible (la crueldad extrema, el sufrimiento atroz) como pacificar la vista en la apoteosis de la más insignificante redundancia. En uno y otro casos, las exigencias del rito comunicativo, propias de un mundo de sujetos responsables e ilustrados, son apenas el resto de un ethos pretérito, el un tiempo en el que, puesto que «comunicar» con el Otro no se daba por sentado ni era obligatorio, tal vez fue posible que la comunicación revistiera importancia, y tuviera una dramática y rica profundidad potencial.

\section{ESTÉTICA Y TRANSESTESIA}

Pero si la ética abandona la imagen porque no es compatible con la plena reversibilidad de la negatividad y de la positividad sociales ofrecidas al voyeurismo, no sucede lo mismo con la estética, dimensión antropológica del 
signo que la iconosfera actual está reforzando hasta desconocidos umbrales de paroxismo. Ahora bien, acotar la relevancia que la conciencia de estar elaborando o consumiendo algo «bello» ha adquirido para el desarrollo de los medios icónicos contemporáneos reclama rastrear previamente la genealogía de la idea misma de «estética» en lo que a las ciencias del sentido (humanidades y ciencias sociales) se refiere. Y es así que la «función estética» atribuida al lenguaje por la lingüística, ese momento de elocuente plenitud en el que el habla o la escritura parecen manar por sí y para sí mismos, serenamente ajenos a toda contaminación utilitaria, es una de las nociones científicas que más honda repercusión han tenido sobre la forma en que concebimos nuestro universo simbólico en general.

Un ejemplo: la mayoría de las prácticas institucionales que involucran a la literatura dentro del sistema de enseñanza exigen como su fundamento implícito la creencia (en la acepción sociológica del término) en que existe una magnitud poética del lenguaje aislable y definible en sí misma, y en que ésta es uno de sus constituyentes esenciales. Quienes se consagran a la literatura deben interiorizar que la literatura es antes que nada un discurso narcisista, una palabra que se expande como un lujo verbal, un exceso gratuito y gratificante 4 . Tal entendimiento de la lengua y de lo literario choca no obstante contra las duras evidencias del análisis social: en el macromercado cotidiano, la lengua parece más bien una herramienta puesta al servicio de la producción y del intercambio; y los literatos, salvedad hecha de una pequeña fracción de autores inscritos en las instituciones pedagógicas o intelectuales, no suelen atribuir a sus obras una finalidad primordialmente estética: al contrario, suelen hablar de la literatura en términos más pragmáticos de comunicación, pensamiento o incluso acción. Así las cosas, es legítimo preguntarse si la estetización de la lengua y la literatura no será sobre todo el producto de una ideología profesional, el resultado de una cogitación desarraigada y efectuada en el ámbito protegido de una scholé o tiempo escolástico ajeno al trabajo y a la necesidad social. No se trata, naturalmente, de que el lenguaje no pueda hacerse hermoso o cargarse de una sobredeterminación estética en cualquier momento de su existencia, sino de que, bien analizada, la estética viene a ser, en cuanto supuestamente discriminable y definible, la más forzada, especializada y ontologizada de las funciones atribuidas al lenguaje: una hipóstasis de académico.

Respecto de la imagen la situación teórica resulta de un significativo paralelismo: la imagen ganó su crédito estético y su autonomía artística sólo a

${ }^{4}$ Detrás de este postulado se encuentra la filosofía del arte kantiana y neokantiana, que ha canonizado en la historia del pensamiento occidental la ideológica separación radical del arte y de la vida. 
partir del siglo XIX, época en la que es elevada además a la categoría de objeto de un saber autónomo, de un discurso específico, en tanto que hasta entonces había sido fundamentalmente un instrumento al servicio de la transmisión intelectual, un auxiliar de la palabra escrita (religiosa, en las miniaturas y estampas; política, en la pintura oficial de corte; científica o paracientífica, en las ilustraciones de la Enciclopedia; etc.). Tal carácter secundario de la imagen en relación con la lengua natural, y de su componente estético comparado con su contenido cognitivo, es justo lo que se ha invertido en el mundo tardo y postmoderno, y ello ha ocurrido así tanto en el plano pragmático de las prácticas sociales cotidianas como en el epistémico de la acción cultural y científica. Hoy los signos icónicos son netamente prioritarios frente a los signos lingüísticos, y la rentabilidad ideológica de las imágenes se cifra, precisamente, en su drástica e insuperable estetización, en su avasalladora presencia ubicua como vehículos de un embellecimiento integral de la vida por la satisfacción siempre en curso de la mirada. No queda fragmento de espacio que no haya sido convertido en soporte de la actividad atencional-contemplativa, y sometido a una filtración de la solución estetizante: si la enciclopedia icónica nos ha enseñado a pasar las figuras del mundo por el tamiz de sus representaciones pictóricas, fotográficas o cinematográficas, el arte abstracto, en sus variantes geométrica o matérica, estructural o expresionista, ha realimentado nuestra visión con esquemas perceptivos de los que ya no podemos librarnos cuando vemos o sentimos las formas, texturas o colores del mundo natural, pero de los que el sujeto ideal-típico de nuestras sociedades no es consciente, puesto que dichos esquemas refuerzan los automatismos culturales instalados en él por su socialización. Bajo la presión de los megamedios de masas y del aparato tecnocientífico, de la pseudocultura y de la mala ilustración universales, parece haber cuajado una nueva doxa simbólica que, cual filtro deformante, impide la visión desprejuiciada: el ser humano contempla a través de lo ya contemplado, construye mediante lo preconstruido, y carga su organismo de estímulos estéticos que otros han fabricado para él en los laboratorios de producción de la experiencia social.

Lo que resta por dilucidar es si tal embellecimiento ecuménico e irreflexivo de la realidad visual en todos sus pliegues y recodos merece aún la apelación de «estética de la imagen», o si no sería más apropiado calificarlo de transestesia generalizada, pasión del mirar como si lo mirado fuera hermoso por el mero hecho de imponerse a la mirada dentro de un entorno ganado de antemano para los transportes de la sensibilidad. Y una segunda duda también, derivada de la primera: la de decidir si, a pesar de todo, no valdría más entregarse, al menos idealmente, a un esfuerzo de desaprendizaje perceptivo 
voluntario, que permitiese objetivar lo que se da por supuesto y anular los principios adquiridos de percepción y apreciación culturales, para así, recorriendo reflexivamente los archivos icónicos de la humanidad, salir de la presunta inmediatez de la cultura absorbida como hegeliana «segunda naturaleza» (Adorno, 1992), y escapar a la par de la vivencia tímica primaria y de la creencia condicionada en el valor civilizatorio de la imagen por sí misma. Encantarse con cualquier objeto visible porque ese objeto es visualizable y convertible en icono, y porque ha sido visualizado e iconizado una y mil veces en la tradición del arte, significa rendirse sin condiciones ante la prima de placer añadida por la estética a un acto representacional cuyos fundamentos ya no se ponen en cuestión, y privar por ello a la conciencia de una parte de su libertad (Freud, 2003). Pero quizá lo más llamativo es que esta anestesia crítica provocada por la transestesia visual ha sido aceptada y legitimada por aquellas mismas instancias sedicentemente responsables de mantener la vigilancia sobre el universo simbólico. Pues sucede que las instituciones de la alta cultura y la Universidad han desplazado, en las últimas décadas, su atención desde el discurso de lengua hacia el discurso de la imagen, incorporando al inventario de los objetos de estudio «autorizados» géneros de producción icónica como el cómic, la fotonovela y telenovela, el cine fabricado según el Modelo Narrativo Canónico de marchamo holywoodiense, el juego de vídeo calificado de «interactivo», y un largo etcétera.

Las causas de esta ampliación de los programas de investigación han sido a buen seguro al mismo tiempo internas y externas al campo de la ciencia. Internas, porque se había hecho patente cierto estancamiento de las líneas de trabajo más tradicionales que confluían en los textos de lengua: trastocada la poética literaria en un juego de lenguaje intranscendente bajo el influjo de la deconstrucción y de los «estudios culturales» (por mucho que ambos se deshagan en invocaciones puramente retóricas al progresismo social), relegado el análisis del discurso a un segundo plano por su extemporánea voluntad de combate político, reducida la lingüística a mero auxiliar de las industrias de la lengua y a proveedora de teorías para la inteligencia artificial y las ciencias cognitivas, es comprensible que los analistas de la cultura hayan deseado, haciendo gala de una plausible curiosidad científica, explorar los nuevos soportes del proceso civilizatorio. Y causas externas, puesto que este cambio en el centro de interés científico, presentado como reto autónomo de «modernización», difícilmente puede ocultar su condición de maniobra impuesta a los investigadores por la urgencia heterónoma de asegurarse la supervivencia profesional ante la todopoderosa industria de la cultura de masas. A fin de justificar tal reconversión científica (aunque no haya que menos- 
preciar el influjo al respecto del relevo mecánico de generación de investigadores acaecido hacia los años ochenta), los estudiosos no tuvieron más remedio que recuperar y reivindicar dudosos productos icónicos antaño considerados por ellos mismos como subcultura, colaborando así en la ceremonia postmoderna de la confusión de los niveles culturales.

Ahora bien, este tránsito desde la suspicacia al ensalzamiento, desde la hermenéutica de la sospecha hasta la de la sublimación aplicada a los prefabricados pseudoculturales, requería ser explicado con argumentos que pudieran ayudar a los investigadores a justificarse y a hacer olvidar su doble «traición»: en cuanto representantes de la independencia frente a las esferas de la política y de la economía, y en tanto guardianes de la exigencia intelectual. Dos han sido las tesis avanzadas con tal propósito. La primera, sugiere que la estética o transestesia visual global que invade nuestra experiencia contendría por fin la promesa de una democratización verdadera de la participación en los bienes culturales, ya que el aprendizaje de la «cultura visual» se realiza bajo modalidades menos selectivas y elitistas que el de la cultura escrita, siendo además potencialmente universal — válido para todos los grupos humanos-.

La segunda, tesis reza que en la permanente intensidad emocional y afectiva espoleada por la transestesia cultural en nuestros cuerpos se hallaría la clave del acceso a una «vida lograda», dado que ésta ya no pasa por la sumisión de las facultades sensibles al imperio despótico de la razón (tan ajena, desde Kant, al «juicio de gusto»), y que la ética ha dejado de ser vínculo — dramático - con el otro para devenir cura sui, diálogo atento consigo mismo y asistencia esmerada del individuo a su vida individual. Aun cuando acaso ambos razonamientos no estén enteramente desprovistos de pertinencia, no parece dudoso que uno y otro son también, y ante todo, racionalizaciones de lo que al fin y al cabo representa una capitulación - violentamente forzada y desgraciadamente forzosa - de la investigación ante el orden de necesidades culturales impuesto por el capitalismo tardío. Al defender semejante idea rebajada de la cultura como pasto de la visión, y tal modo de relación lúdica con ella como trueque de la ética (de la palabra) por la estética (de la imagen), los investigadores actúan en perjuicio de su propia identidad de intelectuales. Olvidando los otros dos valores de la tríada clásica, al margen de los cuales el papel social del intelectual pierde consistencia, los investigadores sólo se atreven ya a promover como objetivo la Belleza —en sus variedades más inmediatas y menos refinadas, en su dimensión transestésica-; por lo que concierne a la Verdad y al Bien, es decir, al rigor epistemológico y a la esperanza sociopolítica, inseparables del concepto mismo de ciencia (la 
cual está fundada ab initio sobre la bondad de lo verdadero para la colectividad), todo investigador en humanidades contemporáneo y bien informado sabe que no es ni conveniente ni rentable ocuparse de ellos.

\section{REFLEXIVIDAD Y PANINTERPRETACIÓN}

La reflexividad es una de las propiedades que hacen del lenguaje el vehículo por excelencia del conocimiento humano, y también una de sus más vertiginosas características. Las lenguas humanas no sólo se refieren al mundo natural o social, explorando a la par al hacerlo la enciclopedia cultural en la que aquél está parcialmente contenido; también se indagan tenazmente a sí mismas, en aplicación de una suerte de programa de revisión y autocorrección de su propia actividad que tiende a ajustarlas cada vez mejor a las funciones que han de desempeñar. La centralidad epistemológica que con frecuencia se ha atribuido a las lenguas naturales, muy criticada en las últimas décadas pero de retorno en el campo científico, parece por tanto bastante justificada. El lenguaje, además de ser capaz de absorber y de expresar — de transponer- el sentido de cualquier otro sistema de signos (por ejemplo, de las imágenes artificiales, o incluso de la música, en un caso extremo), puede hacer explícito su propio sentido y los mecanismos mediante los que éste se construye. Toda comunicación lingüística, se ha dicho con frecuencia, es también una metacomunicación, un debate abierto sobre los modos en que algo está siendo comunicado durante su mismo proceso de transmisión o circulación (Habermas, 1991). No importa que a veces se abuse de la metacomunicación cuando no se tiene nada relevante que comunicar: aunque escribir para decir que se está escribiendo puede considerarse con tanto derecho una obviedad como el summum de la autoconciencia, la avalancha de metaliteratura producida en tiempos recientes no degrada la función metacomunicativa ni la vuelve sospechosa en sí misma. Ella es la mejor garantía de que el sujeto del habla o de la escritura no se resuelve y se agota sin más en su enunciado, sino que lo transciende, y también de que el significado de éste último resulta a la vez de un tenaz trabajo de remodelación del lenguaje y de una negociación, de una transacción con su destinatario.

¿Están en condiciones las imágenes artificiales de reclamar para sí ese mismo nivel de complejidad y semejantes garantías de procedimiento? No cabe duda de que los iconos pueden tomar otros iconos como materia prima y reelaborarlos, creando así ciertos efectos de saber sobre la iconosfera; de hecho, ese algoritmo de generación icónica está en la base de nuestro sistema tecnocientífico de producción de imágenes, y por tanto es clave en la gestión 
contemporánea de la enciclopedia icónica. El ojo avisado distingue sin vacilación en grandes zonas del flujo de imágenes la reformulación permanente de un limitado número de prototipos icónicos o de textos visuales; y ese mismo ojo logrará también hacer una lectura metaicónica de ellos desde el momento en que pase a considerar que el objetivo de tales representaciones visuales consiste no en proporcionar al receptor una experiencia referencial o simulatoria, emocional o timopática, conativa o autoperformativa, fática o saturativa, estética o transestésica, sino en elevarlo a la categoría de usuario lúcido de un patrimonio convencional de imágenes constantemente recicladas por la industria cultural. Falta sin embargo por saber si tal lectura del icono es resultado de un fenómeno intencional o atencional, si el consumo «meta» de las imágenes es promovido por su productor, impuesto por la estructura semiótica del propio icono, o decidido por la mirada experta como una modalidad peculiar de recepción de la imagen, la más culta y sofisticada posible; es decir, habría que dilucidar si el ojo avisado puede permitirse generalizar sin más sus refinadas prácticas receptivas, neutralizadoras y autofruitivas, como si éstas fuesen al mismo tiempo las que mejor dan cuenta de las propiedades de los iconos y las que ejecuta el común de los receptores. La constante y dominante re-producción icónica en la semiosfera contemporánea no es sólo un fenómeno de reactualización fría y crítica del thesaurus icónico: es ante todo un hecho masivo de imposición y de construcción simbólicas, del que los intelectuales creen poder escapar merced a su único privilegio seguro, la distancia crítica, y que se sienten felices de poder legitimar apelando a la diversidad democrática en los usos concebibles de la cultura.

En el filme de Quentin Tarantino o de Oliver Stone en el que el espectador vulgar ve una carnicería, el intelectual descifra una reflexión irónica sobre el uso de las imágenes de violencia por los media; a las películas de Pedro Almodóvar, con cuya desenfadada explotación de los tópicos costumbristas postmodernos disfruta el comprador medio de una entrada, el intelectual les aplica una hermenéutica redentora que vislumbra en ellas ejemplos de profundidad metanarrativa. Pero del mismo modo que no basta con engastar un fragmento de una película en otra (The Prowler de J. Losey, 1950, fugazmente incorporada en Kika, 1993), ni con ensayar el remake irónico (de The Collector de W. Wyler, 1965, en Átame, 1989) para alcanzar la magnitud autorreflexiva del signo, así tampoco los críticos de cine pueden tomar sus modalidades socioprofesionales de explotación de los filmes por rasgos objetivos de éstos, o por formas habituales de su consumo. No se trata únicamente de que la capacidad «meta» de la imagen respecto de otras imágenes sea mucho más reducida que la de la lengua natural en relación con otra len- 
gua natural: aunque existen confirmados intentos metacinematográficos (Passion de J.-L. Godard, 1982, o The Player de R. Altman, 1991, sin ir más lejos), y aunque la reflexividad admite múltiples grados, desde la simple connotación de autoconciencia hasta la recursividad metatextual, la mayoría de dichos productos pretendidamente metaicónicos no son en verdad ni analíticos ni explicativos; funcionan, al contrario, como artefactos citacionales, estimuladores de una complicidad de primer grado entre el cineasta y su público. Tal complicidad consiste esencialmente en empujar al receptor a reconocer, en las imágenes que está contemplando, una alusión o una transformación parcial de alguno de los iconemas sedimentados en su memoria personal como espectador, subconjunto del conjunto móvil constituido por la enciclopedia icónica. La operación de reconocimiento inducida por la imagen reformulada genera así un doble y demagógico rédito psíquico. En primer lugar, el espectador ve muy simplificado su trabajo de descodificación de la propuesta icónica, ya que se le invita a aplicarle a ésta esquemas de percepción y de apreciación previamente disponibles en su aparato cognitivo; esquemas que, además, la versión original de lo que se está reactualizando sin duda había contribuido a crear, con lo cual se cierra el círculo entre lo constituyente — los iconos - y lo constituido — sus bases de aprehensión y evaluación-. En segundo lugar, la apreciación subjetiva de la facilidad y «naturalidad» en la interpretación de la imagen, de esta suerte alentada en el espectador, se complementa con la euforia que todo acto de re-conocimiento exitoso produce en su agente, en cuanto que le inspira el sentimiento de pertenencia «espontánea» a una clase de individuos, la de los receptores competentes; y más allá de éstos, a una comunidad — hemos afirmado que ilusoria - de comunicación cuyo patrimonio cultural circula generosamente entre sus miembros. Mecanismo de reducción de toda disonancia cognitiva potencial, sedante de la angustia siempre generada por el enfrentamiento con la novedad, oferta de satisfacción para un narcisismo cultural secundario, la citacionalidad presuntamente «meta» de tantos documentos icónicos en el presente se asemeja más bien a un juego subcultural autosatisfecho y heterogratificante, una maniobra cuantitativa sobre la transtextualidad icónica, que hace buena la etimología mitológica de la palabra hermenéutica: Hermes es el dios de las transformaciones engañosas y de la manipulación mediante signos, el patrón y protector de mentirosos y ladrones... pero también el dios lleno de encanto que inventó la lira y la flauta para diversión de los mortales.

Las imágenes artificiales que fabrica la industria cultural, salvo contadas excepciones, no consiguen desempeñar, y mucho menos por sí solas, sin el auxilio del discurso lingüístico en forma de textos de acompañamiento (que, 
en el caso de los filmes, comentan, analizan, y en realidad producen casi por entero el sedicente valor del documento icónico «meta»), una función metaicónica. Su verdadero cometido es el de la sugestión de consenso, de la seducción cultural y del disfrute de las anticipaciones colmadas. En lugar de modificarlo, apuntalan el horizonte de expectativas del espectador, confirmando a éste en lo que ya es de todos modos porque es lo que ha devenido en el interior de su cultura (Adorno y Horkheimer, 1966): un comprador de sus propias señas de identidad, que ya no le identifican como individuo ni como parte de grupo, sino en tanto consumidor de lo social hecho símbolo. Sería injusto, pese a la referencia a Hermes más arriba apuntada, identificar tal función sin más con la propia de la hermenéutica, puesto que algunos de los teóricos de la interpretación en el campo de la filosofía (P. Ricoeur), el derecho (E. Betti) o la literatura (P. Szondi) no trabajaron con semejantes objetivos acríticos, aunque lo que vaya quedando para la vulgata del momento sea la opinión de los que sí lo hacen o hicieron (G. Vattimo, R. M. Unger o P. de Man). Llamemos entonces a la anterior la función paninterpretativa de la imagen artificial: al vértigo de la remisión ilimitada entre los textos culturales icónicos esa función de la imagen añade el fomento de la variedad de autocomplacencia propia de los intelectuales - ya bastante criticada aquí-, su creencia ingenua en que es suficiente con acumular capital simbólico para responder a las exigencias del conocimiento. Fe que alimenta la confusión presente y nada inocente entre cultura y ciencia, entre los signos aparentes del saber y el saber sobre los signos de la apariencia, y que empuja a confortar la doxa justo porque se carece de los instrumentos requeridos para transformar la interpretación dóxica en genuina certidumbre reflexiva y autorreflexiva, en ese tipo de verdad (condicional e histórica) que lleva el nombre de episteme.

\section{AUTOCORRECCIÓN}

¿Hablar contra la imagen? ¿Resucitar una variante actualizada, cientista, de la iconoclasia - suspicacia contra los iconos o franca detestación de ellos que, por otra parte, nunca ha desaparecido? Sólo quien no haya experimentado nunca la emoción estética ante una pintura, participado del mundo posible narrativo de una película, aprendido de un gráfico o de un esquema informático, o incluso superado una enfermedad gracias al diagnóstico de un escáner, una ecografía o una resonancia magnética, podría incurrir en semejante despropósito; y aun así todavía tendría que protegerse del sueño y del ensueño, pantallas pulsionales donde se despliegan las más ricas moda- 
lidades de imágenes, y que renunciar a la postre al pensamiento, ya que si la lengua natural es el soporte básico del pensar también se piensa con imágenes y en imágenes. No, esa no es, ni podría nunca ser, la cuestión. La cuestión está en otro sitio: en lo que el modelo socioeconómico y el aparato tecnocientífico hacen con el sujeto al sujetarlo a una cultura de la imagen que es al mismo tiempo una imagen (empobrecida y neutralizada) de la cultura. Contra esa imagen, la palabra, sí, pero contra esta palabra crítica y negativa, las imágenes que aún están por crearse cuando se den las condiciones necesarias para ello, y que contienen en su futuro cultural un atisbo de utopía.

\section{REFERENCIAS BIBLIOGRÁFICAS}

Adorno, Th. W. (1992). Dialéctica negativa. Madrid: Cátedra.

Adorno, Th. W. y HorkHeimer, M. (1966). Sociológica. Madrid: Taurus.

Althusser, L. (1977). Posiciones. Barcelona: Anagrama.

BAUdRILlard, J. (1993). Cultura y simulacro. Barcelona: Kairós.

Bettetini, G. (1984). La conversación audiovisual. Madrid: Cátedra.

BORDWELL, D. (1995). El significado del filme. Inferencia y retórica en la interpretación cinematográfica. Barcelona: Paidós.

Eco, U. (1999). Kant y el ornitorrinco. Barcelona: Lumen.

EISENSTEIn, S. M. (2001). Hacia una teoría del montaje. Barcelona: Paidós.

FREUd, S. (2003). El chiste y su relación con el inconsciente. Madrid: Alianza.

HABERMAS, J. (1991). Conciencia moral y acción comunicativa. Barcelona: Ediciones 62.

HaYAKawa, S. I. (1972). Language in thought and Action. New-York: Harcourt.

Junger, E. (1990). El trabajador. Barcelona: Tusquets.

Mitchell, W. J. (1992). The Reconfigured Eye: Visual Truth in the Post-Photographic Era. Cambridge-London: MIT Press.

SARTRE, J.-P. (1940). L'imaginaire. Paris: Gallimard.

Sontag, S. (2003). Ante el dolor de los demás. Madrid: Alfaguara.

VIRILIO, P. (1997). El cibermundo. La política de lo peor. Madrid: Cátedra. 